

\section{DISCLAIMER}

This report was prepared as an account of work sponsored by an agency of the United States Government. Neither the United States Government nor any agency Thereof, nor any of their employees, makes any warranty, express or implied, or assumes any legal liability or responsibility for the accuracy, completeness, or usefulness of any information, apparatus, product, or process disclosed, or represents that its use would not infringe privately owned rights. Reference herein to any specific commercial product, process, or service by trade name, trademark, manufacturer, or otherwise does not necessarily constitute or imply its endorsement, recommendation, or favoring by the United States Government or any agency thereof. The views and opinions of authors expressed herein do not necessarily state or reflect those of the United States Government or any agency thereof. 


\section{DISCLAIMER}

Portions of this document may be illegible in electronic image products. Images are produced from the best available original document. 
Printed in the United States of America Available from

Clearinghouse for Federal Scientific and Technical Information National Bureau of Standards, U. S. Department of Commerce Springfield, Virginia 22151

Price: Printed Copy \$3.00; Microfiche $\$ 0.65$

\section{LEGAL NOTICE}

This report was prepared as an account of Government sponsored work. Neither the United States, nor the Commission, nor any person acting on behalf of the Commission:

A. Makes any warranty or representation, express or implied, with respect to the accuracy. completeness, or uspfulness of the informatiun cuntalned in this report, or that the use of any information, apparatus, method, or process disclosed in this report may not infringe privately owned rights; or

B. Assumes any liabilities with respect to the use of, or for damages resulting from the use of any information, apparatus, method, or process disclosed in this report.

As used in the above, "person acting on behalf of the Commission" includes any employee or contractor of the Commission, or employee of such contractor, to the extent that such employee or contractor of the Commission, or employee of such contractor prepares, disseminates, or provides access to, any information pursuant to his employment or contract with the Commission, or his employment with such contractor. 
This report was prepared as an account of Government sponsored work. Nelther the United States, nor the Commission, nor any person acting on behalf of the Commission:

A. Makes any warranty or representation, expressed or implled, with respect to the accuracy, completeness, or usefulness of the information contalned in this report, or that the use of any information, apparatus, method, or process disclosed in this report may not infringe privately owned rights; or

B. Assumes any liabilities with respect to the use of, or for damages resulting from the use of any information, apparatus, method, or process disclosed in this report.

As used in the above, "person acting on behalf of the Commission" includes any employee or contractor of the Commlssion, or employee of such contractor, to the extent that such employee or contractor of the Commission, or employee of such contractor prepares, disseminates, or provides access to, any information pursuant to bis employment or contract with the Commisston, or his employment with such contractor.

\section{BURNUP DETERMINATION \\ OF NUCLEAR FUELS}

PROJECT REPORT

FOR THE QUARTER OCTOBER 1 - DECEMBER 31, 1966

Issued: October 1967

Chemistry

TID-4500

Edited By

Frederick L. Lisman, William J. Maeck, and James E. Rein

IDAHO NUCLEAR CORPORATION
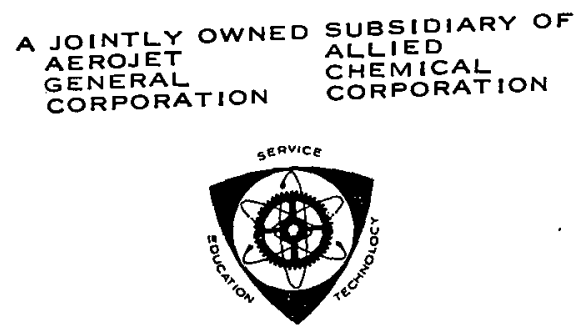

U. S. Atomic Energy Commission Research and Development Report

Issued Under Contract AT(10-1)-1230

Idaho Opcrations Officc 


\section{BURNUP DETERMINATION}

OF NUCLEAR FUELS

PROJECT REPORT

FOR THE QUARTER OCTOBER 1 - DECEMBER 31, 1966

\section{Edited by}

Frederick L. Lisman, William J. Maeck, and James E. Rein

Contributing Personnel

Analytical Development Section

W. A. Emel

R. E. Foster

M. E. Kussy

S. F. Marsh

Mass Spectrometry Group

R. M. Abernathey

L. W. Buttars

L. L. Dickerson

R. E. McAtee

R. A. Nielsen

A. H. Toepfer

G. D. Workman

Operatione Analysis (Statistics)

F. W. Spraktes 
In this continuing program to develop methods for the accurate determination of the burnup of nuclear fuels, the main emphasis this quarter was the measurement of the absolute, thermal fission yields of stable $\mathrm{Cs}-133,30.3 \mathrm{y} \mathrm{Cs}-137$ and the stable $\mathrm{Zr}-91,-92,-93,-94$, and -96 isotopes for U-233 and U-235 by isotope dilution mass spectrometry. These values, determined on each of four dissolved U-233 capsules and three U-235 capsules, are:

\section{Fission Yields for U-233}

\begin{tabular}{|c|c|c|c|c|}
\hline \multirow[b]{2}{*}{ Isotope } & \multirow[b]{2}{*}{$6-2-4$} & \multicolumn{2}{|c|}{ Capsule } & \multirow[b]{2}{*}{$6-5-1$} \\
\hline & & $6-4-2$ & $6-4-3$ & \\
\hline Cs-133 & $6.10 \pm 0.09$ & $6.08 \pm 0.10$ & $5.81 \pm 0.11$ & $6.45 \pm 0.16$ \\
\hline $\mathrm{Cs}-137$ & $6.94 \pm 0.09$ & $6.90 \pm 0.11$ & $6.67 \pm 0.13$ & $7.33 \pm 0.16$ \\
\hline $\mathrm{Zr}-91$ & $6.56 \pm 0.08$ & $6.68 \pm 0.1 .1$ & $6.38 \pm 0.12$ & $6.96 \pm 0.15$ \\
\hline Zr-92 & $6.66 \pm 0.08$ & $6.76 \pm 0.11$ & $6.44 \pm 0.12$ & $7.08 \pm 0.15$ \\
\hline Zr-93 & $7.06 \pm 0.08$ & $7.1 .6 \pm 0.12$ & $6.81 \pm 0.13$ & $7.53 \pm 0.16$ \\
\hline$Z r-94$ & $6.91 \pm 0.08$ & $6.95 \pm 0.11$ & $6.65 \pm 0.12$ & $7.31 \pm 0.16$ \\
\hline $\mathrm{Zr}-96$ & $5.88 \pm 0.07$ & $5.85 \pm 0.10$ & $5.57 \pm 0.10$ & $6.16 \pm 0.13$ \\
\hline
\end{tabular}

\section{Fission Yields for U-235}

Isotope
$\mathrm{Cs}-133$
$\mathrm{Cs}-137$
$\mathrm{Zr}-91$
$\mathrm{Zr}-92$
$\mathrm{Zr}-93$
$\mathrm{Zr}-94$
$\mathrm{Zr}-96$

$$
6-2-2
$$

$6.72 \pm 0.04$

$6.27 \pm 0.04$

$5.90 \pm 0.04$

$5.96 \pm 0.04$

$6.35 \pm 0.05$

$6.40 \pm 0.05$

$6.24 \pm 0.04$

Capsule

$\begin{array}{cc}\text { Capsule } & \frac{6-6-2}{6-1} \\ 6.71 \pm 0.08 & 6.83 \pm 0.13 \\ 6.22 \pm 0.14 & 6.32 \pm 0.09 \\ 5.90 \pm 0.08 & 5.90 \pm 0.09 \\ 5.92 \pm 0.08 & 5.97 \pm 0.09 \\ 6.31 \pm 0.08 & 6.34 \pm 0.09 \\ 6.45 \pm 0.08 & 6.42 \pm 0.09 \\ 6.23 \pm 0.08 & 6.22 \pm 0.09\end{array}$


These values are tentative and as additional capsules are analyzed, refined data will be reported.

Previous project reports are:

Annual - 1962

Annual - 1963

Annual - 1964

Quarter, January-March, 1965

Quarter, April-June, 1965

Quarter, July-September, 1965

Quarter, October-December, 1965

Quarter, January-March, 1966

Quarter, April-June, $1966^{\circ}$

Quarter, July-September, 1966
TID-17385

IDO-14649

IDO- 14656

IDO- 14660

IDO -14663

IDO- 14667

IDO-14676

IIIO-14678

IDO-14681

TN-1064 
CONTENTS

SUMMARY . . . . . . . . . . . . . . . . . . . . . $\mathrm{.}$. .

INTRODUCTION . . . . . . . . . . . . . . . . . . 1

ABSOLUTE THERMAL FISSION YIELDS OF Cs-133 AND Cs-137 FOR U-233
AND U-235 . . . . . . . . . . . . . . . . . . . . . . 2

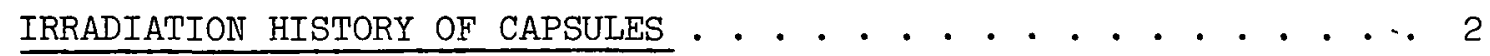

DISSOLUTION OF CAPSULES . . . . . . . . . . . . . . . . . . 2

CHEMICAL SEPARATION OF CESIUM . . . . . . . . . . . . . . . 2

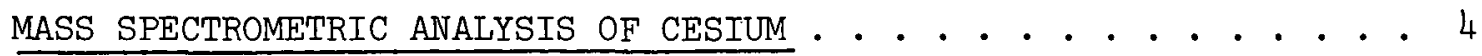

FISSION YIELDS OF CS-133 AND Cs-137 FOR U-233. . . . . . . . . . . . 4

FISSION YIELDS OF Cs-133 AND Cs-137 FOR U-235 • . . . . . . . . . 6

ABSOLUTE THERMAL FISSION YIELDS OF STABLE ZIRCONIUM ISOTOPES

FOR U-233 AND U-235... . . . . . . . . . . . . . . . .

CHEMICAL SEPARATION OF ZIRCONIUM . . . . . . . . . . . . . . . 16

MASS SPECTROMETRIC ANALYSIS OF ZIRCONIUM . . . . . . . . . . . . . . I6

FISSION YIELDS OF THE ZIRCONIUM ISOTOPES FOR U-233. . . . . . . • . 16

FISSION YIELDS OF THE ZIRCONIUM ISOTOPES FOR U-235 . . . . . . . . 18

REFERENCES . . . . . . . . . . . . . . . . . . • . 27

APPENDIX I - PROCEDURE FOR THE SEPARATION AND MASS SPECTROMETRIC

ANALYSIS OF FISSION PRODUCT CESIUM . . . . . . . . . . . . . 29

APPENDIX II - PROCEDURE FOR THE SEPARATION AND MASS SPECTROMETRIC

ANALYSIS OF FISSION PRODUCT ZIRCONIUM . . . . . . . . . . . . 4I

FIGURES

I. COMPUTER PROGRAM SCHEMATIC FOR BUILDUP AND BURNOUT OF

FISSTON PRODUCT CFSIUM . . . . . . . . . . . . . . . 8

II. COMPUTER PROGRAM SCHEMATIC FOR BUILDUP AND BURNOUT OF

FISSION PRODUCT ZIRCONIUM . . . . . . . . . . . . . . . I9 
TABLES

I. COMPOSITION AND IRRADIATION HISTORY OF STANDARD

BURNUP CAPSULES. . . . . . . . . . . . . . . 3

II. PRECISION OF OVERALL PROCEDURE ........... 5

III. THERMAL FISSION YIELDS OF Cs-133 AND Cs-137 FOR U-233

FROM CAPSULE 6-2-4................. . . 9

IV. THERMAL FISSION YIELDS OF Cs-133 AND Cs-137 FOR U-233

FROM CAPSUlE 6-4-2 . . . . . . . . . . . 10

V. THERMAL FISSION YIELDS OF Cs-133 AND Cs-137 FOR U-233

FROM CAPSULE 6-4-3 . . . . . . . . . . . . . II

VI. THERMAL FISSION YIELDS OF Cs-133 AND Cs-137 FOR U-233

FROM CAPSULE 6-5-1.............. 12

VII. THERMAL FISSION YIELDS OF Cs-133 AND Cs-137 FOR U-235 FROM CAPSULE 6-2-2 . . . . . . . . . . . . 13

VIII. THERMAL FISSION YIELDS OF Cs-133 AND Cs-137 FOR U-235 FROM CAPSULE 6-4-1............... 14

IX. THERMAL FISSION YIELDS OF Cs-133 AND Cs-137 FOR U-235 FROM CAPSULE 6-6-2................... 15

X. COMPARISON OF ISOTOPIC DISTRIBUTION OF NATURAL 7.IRCONTUM . . . . . . . . . . . . . . . . . . . . 17

XI. THERMAL FISSION YIELDS OF STABLE ZIRCONIUM ISOTOPES FOR U-233 FROM CAPSULE 6-2-4 ........... 20

XII. THERMAL FISSION YIELDS OF STABLE ZIRCONIUM ISOTOPES FOR U-233 FROM CAPSULE 6-4-2 . . . . . . . . . . 21

XIII.THERMAL FISSION YIELDS OF STABLE ZIRCONIUM ISOTOPES FOR U-233 FROM CAPSULE 6-4-3 . . . . . . . . . . 22

XIV. THERMAL FISSION YIELDS OF STABLE ZIRCONIUM ISOTOPES FOR U-233 FROM CAPSULE 6-5-1........... 23

XV. THERMAL FISSION YIELDS OF STABLE ZIRCONIUM ISOTOPES FOR U-235 FROM CAPSUle 6-2-2 .............. 24 
XVI. THERMAL FISSION YIELDS OF STABLE ZIRCONIUM ISOTOPES FOR U-235 FROM CAPSULE 6-4-1 . . . . . . . . . . 25

XVII.THERMAL FISSION YIELDS OF STABLE ZIRCONIUM ISOTOPES FOR U-235 FROM CAPSULE 6-6-2 . . . . . . . . . 26 
BURNUP DETERMINATION OF NUCLEAR FUELS

\section{INTRODUCTION}

The objective of this project is the development of methods for the accurate determination of burnup of nuclear fuels. The emphasis is on power reactor fuels having long residence time and high burnup rather than on short term, experimental irradiations. The principal measurement technique under study is chemical analysis for fission products. The use of long lived, radiochemically determined fission products is not applicable because the errors of the in-pile decay corrections are magnified with long term irradiations, the nuclear constants are not known with sufficient accuracy, and the few available nuclides, Cs-137 and Sr-90, are volatile. The use of stable fission product nuclides, determined by 1sotope dilution mass spectrometry, has therefore been selected. The degree of reliability of a burnup determination based on stable fission product analysis depends on three factors; the accuracy of the values used for the fission yields, the linearity between the number of fissions and the number of fission product atoms present at the end of the irradiation, and the reliability of the analysis methods.

Specific goals of this project are the accurate measurement of the fission yields of selected nuclides for various fissioning isotopes, the selection of fission product nuclides for use as fission monitors for various fuel types, and the development of separation and mass spectrometric analysis methods for these nuclides. Presently, experiments are in progress to measure the absolute thermal fission yields for U-233, U-235, Pu-239, and Pil-24.1 to a high degree of accuracy. Later in the program, fast fission yields will be measured.

Initial values for many U-233 and U-235 thermal fission yields have been reported in previous reports IDO-14660, IDO-14663, IDO-14667, IDO-14676, IDO-14678, IDO-14681, and IN-1064. 


\begin{abstract}
ABSOLUTE THERMAL FISSION YIELDS OF
\end{abstract}
Cs-133 AND Cs-137 FOR U-233 AND U-235

A major goal of the burnup project is the accurate determination of the thermal fission yields of long-lived and stable fission products. A series of capsules containing weighed amounts of the oxides of highly enriched U-233, U-235, Pu-239, and Pu-241 was prepared and irradiated in the MTR(I). During this quarter the absolute thermal fission yields of Cs-133 and Cs-137 for U-233 and U-235 were determined by isotope dilution mass spectrometry for four U-233 and three U-235 capsules.

\title{
IRRADIATION HISTORY OF CAPSULES
}

The U-233 and U-235 standard burnup capsules, which contained weighed amounts of $\mathrm{U}_{3} \mathrm{O}_{8}$ (highly enriched in the respective isotopes) blended with high purity aluminum powder and weld-sealed in aluminum tubes, were irradiated in the MTR at a position where the unperturbed flux was $6 \times 10^{13} \mathrm{n} / \mathrm{cm}^{2}-\mathrm{sec}$ and the cadmium ratio for cobalt was 15 . The irradiation histories of these capsules are given in Table I.

\section{DISSOLUTION OF CAPSULES, R. E. Foster, Jr., S. F. Marsh}

Dissolution of the capsules was carried out in a 4-in. lead-shielded f'acility. 'l'he dissolution apparatus has been previously described $(1,2)$. The dissolver flask and reflux condenser were fabricated from high-purlty quartz and an acid mixture of $6 \mathrm{M} \mathrm{HCl}-1.6 \mathrm{M} \mathrm{HNO}_{3}$, prepared from quartzdistilled reagents, was the dissolution reagent $(1)$.

The dissolutions proceeded smoothly and were usually complete in $3.5 \mathrm{hr}$. The fission gases, krypton and xenon, appeared approximately $1 \mathrm{hr}$ after the start of dissolution and their evolution continued f'or about ic $\mathrm{hr}$. The final solutions (about $200 \mathrm{ml}$ ) were water clear and contained no residue.

After cooling, the dissolver solutions were quantitatively transferred either to a '¿50-mL class "A" Pyrex volumetric flask or to a callurated 250-ml quartz volumetric flask with the aid of 6M $\mathrm{HCl}-1.6 \mathrm{M} \mathrm{HNO}_{3}$ rinses. The solutions were diluted to volume with quartz distilled water, a Tefloncoated bar magnet was introduced, and the contents were stirred for $1 \mathrm{hr}$.

CHEMICAL SEPARATION OF CESIUM, R. E. Foster, Jr., F. L. Lisman

Cesium is separated carrier-free for analysis by isotope dilution mass spectrometry by scavenging most other fission products and uranium by 
Table I.' COMPOSITION AND IRRADIATION HISTORY OF STANDARD BURNUP CAPSULES

\begin{tabular}{|c|c|c|c|c|c|c|}
\hline Capsule & $\begin{array}{c}\text { Fissionable } \\
\text { Isotope }\end{array}$ & $\begin{array}{c}\text { Enrichment } \\
\text { wt \% } \\
\end{array}$ & 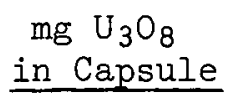 & $\begin{array}{c}\text { MTR } \\
\text { Cycles } \\
\end{array}$ & \% Burnup ${ }^{a}$ & $\begin{array}{c}\text { Reactor } \\
\text { Discharge Date }\end{array}$ \\
\hline $6-2-4$ & $\mathrm{U}-233$ & 99.908 & $58.8 \pm 0.2$ & 8 & $32.40 \pm 0.37$ & August 30,1964 \\
\hline $6-4-2$ & U-233 & 99.908 & $152.4 \pm 0.2$ & 3 & $11.44 \pm 0.18$ & June 8, 1964 \\
\hline $6-4-3$ & U-233 & 99.908 & $126.0 \pm 0.2$ & 3 & $12.39 \pm 0.23$ & June 8, 1964 \\
\hline $6-5-1$ & U-233 & 99.908 & $144.4 \pm 0.2$ & 2 & $8.33 \pm 0.17$ & July 20, 1964 \\
\hline $6-4-1$ & $U-235$ & 99.1633 & $115.2 \pm 0.1$ & 3 & $11.50 \pm 0.13$ & June 8, 1964 \\
\hline $6-6-2$ & $\mathrm{U}-235$ & 99.1633 & $81.9 \pm 0.1$ & 3 & $12.54 \pm 0.18$ & September 15, 1964 \\
\hline $6-2-2$ & U-235 & 99.1633 & $61.2 \pm 0.1$ & 8 & $31.57 \pm 0.19$ & August 30, 1964 \\
\hline
\end{tabular}

a Defined as atoms of major isotope fissioned per 100 initial atoms of major isotope. 
an aluminum hydroxide precipitation. Barium is effectively removed by adding a drop of sulfuric acid to the solution prior to the hydroxide precipitation.

Because natural cesium is monoisotopic (Cs-133), contamination with natural cesium must be prevented as $\mathrm{Cs}_{\mathrm{s}}-133$ is both a fission product and the isotope dilution "spike". For these separations, quartz-distilled reagents were used, all reagents were tested for natural cesium contamination by isotope dilution mass spectrometry using $\mathrm{Cs}-137$ as the "spike", and only quartz or polypropylene ware was used.

The separation procedure is detailed in Appendix I as is the preparation and standardization of the natural cesium "spike".

MASS SPECTROMETRIC ANALYSIS OF. CESIUM, R. M. Abcrnathcy, L. W. Buttars, R. A. Nielsen, R. E. MeAté, G. D. Würkill

The mass spectrometer used for this work was a Nuclide Corporation TDD-1, tandem, 12-in., 90 instrument with three ion detection systems. For the cesium analysis, the Faraday Cage, electrometer, strip chart detection system was used. Details of this instrument, and the various detection systems availabie have been previously reported (2).

Cesium samples, as the chloride, were mounted on a single rhenium filament.

The procedure for the mass analysis of fission product cesium is detailed in Appendix I. Typical data showing the degree of precision obtained for the isotope dilution analysis of three l-ml aliquots of a dissolved, irradiated U-235 sample are summarized in Table II.

FISSION YIELDS OF Cs-133 AND Cs-137 FOR U-233, F. L. Lisman, F. W. Spraktes

The absolute thermal fission yields of $\mathrm{Cs}-133$ and $\mathrm{Cs}-137$ were determined on each of the four, dissolved, U-233 standard burnup capsules. Eight l-ml aliquots (four spiked with known amounts of Cs-133 and four without spike) were analyzed for each dissolved capsule solution. The analysis results and calculated t゙ission yields are summarized in Tables III, through VI. Included are the previously determined radiometric results for $\mathrm{Cs}-137$. Methods of calculation and the error propagation for the determined number of $\mathrm{Cs}-133$ and $\mathrm{Cs}-137$ atoms are given in Appendix I.

The accuracy of the absolute fission yield measurements direclly depends on the accuracy of the determined number of fissions in the irradiated U-233 capsules. For this reason, a large effort was placed. on the preand postirradiation analysis for the atoms of the various uranium isotopes from which the number of fissions was calculated.

To accurately compute the number of U-233 fissions, the following relationship was used:

$$
\mathrm{F}_{3}=\mathrm{U}^{0}-\mathrm{U}
$$


Table II. PRECISION OF OVERALL PROCEDURE Cesium Isotope
(atoms/ml $\times 10^{-15}$ )

Aliquot 133

1

9.912

8.805

2

9.943

8.832

3

9.889

8.785

Avg

9.915

8.807

Std Dev

0.027

0.024

\% std Dev (a)

0.27

0.27

a Standard deviation for an individual result. 
where

$$
\begin{aligned}
& \mathrm{F}_{3}=\text { number of } \mathrm{U}-233 \text { fissions } \\
& \mathrm{U}^{0}=\text { total preirradiated atoms of uranium } \\
& \mathrm{U}=\text { total postirradiated atoms of uranium }
\end{aligned}
$$

To effectively use this relationship, one must account for those atoms of U-235 and U-238 lost by fission and neutron capture. This was done with data obtained from a computer program which simulated the history of the irradiation. The determined number of fissions for each of the U-233 capsules, along with the appropriate references, are given in Tables III thru VI.

The accurate determination of absolute fiission yields, t'or samples which have undergone long term irradiations, requires corrections for the buildup and burnout of the various fission products due to neutron capture. Also required are corrections for the decay of radioactive nuclides.

The method-of correcting for buildup and burnout of the fission products is based on a series of computer programs which simulate the irradiation history of the samples. These programs yield the number of individual fission product atoms formed during the irradiation and their manner of formation. In addition, the programs consider the decay of any radioactive nuclides for the time period between termination of the irradiation and sample analysis. Details of these programs have been previously reported (5).

In the case of $\mathrm{Cs}-133$ and $\mathrm{Cs}-137$, corrections for buildup and burnout by noutron oapturc and $\beta$ dcoay arc modcratc bcing from 2 to $6 \%$. $\Lambda$ schematic diagram of the buildup and burnout program for cesium is given in Figure 1 .

PISSION YIELDS OF Cs-133 AND Cs-137 FOR U-235, F. L. Lisman, F. W. Spraktes

The absolute thermal fission yields of $\mathrm{Cs}-133$ and $\mathrm{Cs}-137$ were determined on each of the three, dissolved, U-235 capsulcs.

Eight l-ml aliquots (four spiked with known amounts of $\mathrm{Cs}-133$ and four without spike) were analyzed from each dissolved capsule solution. The analysis results and calculated fission yields are sumarized in Tables VII thru IX. Included are the previously determined radiometric results for Cs-137. Methods of calculation and the error propagation for the determined number of $\mathrm{Cs}-133$ and $\mathrm{Cs}-137$ atoms are given in Appendix I.

The number of U-235 fissions was calculated from the following relationship:

$$
F_{5}=U^{0}-U
$$


in which:

$$
\begin{aligned}
& F_{5}=\text { number of } \mathrm{U}-235 \text { fissions } \\
& \mathrm{U}^{\circ}=\text { total preirradiated atoms of uranium } \\
& \mathrm{U}=\text { total postirradiation atoms of uranium }
\end{aligned}
$$

The use of this relationship requires corrections for those atoms of U-236 and U-238 lost by neutron capture and subsequent decay to nonuranium isotopes. This was done with data obtained from a computer program which simulated the irradiation history of the various capsules. The determined number of fissions for each of the U-235 capsules, along with the references, are given in Tables VII thru IX.

As in the case of the U-233 thermal fission yields of Cs-133 and Cs-137, correction for the buildup and burnout by neutron capture and $\mathrm{B}^{-}$decay were based on a computer program which simulated the irradiation history of the capsules. 
\% Fission Yie_d

$\underline{\mathrm{U}-233} \quad \underline{\mathrm{U}} 235$

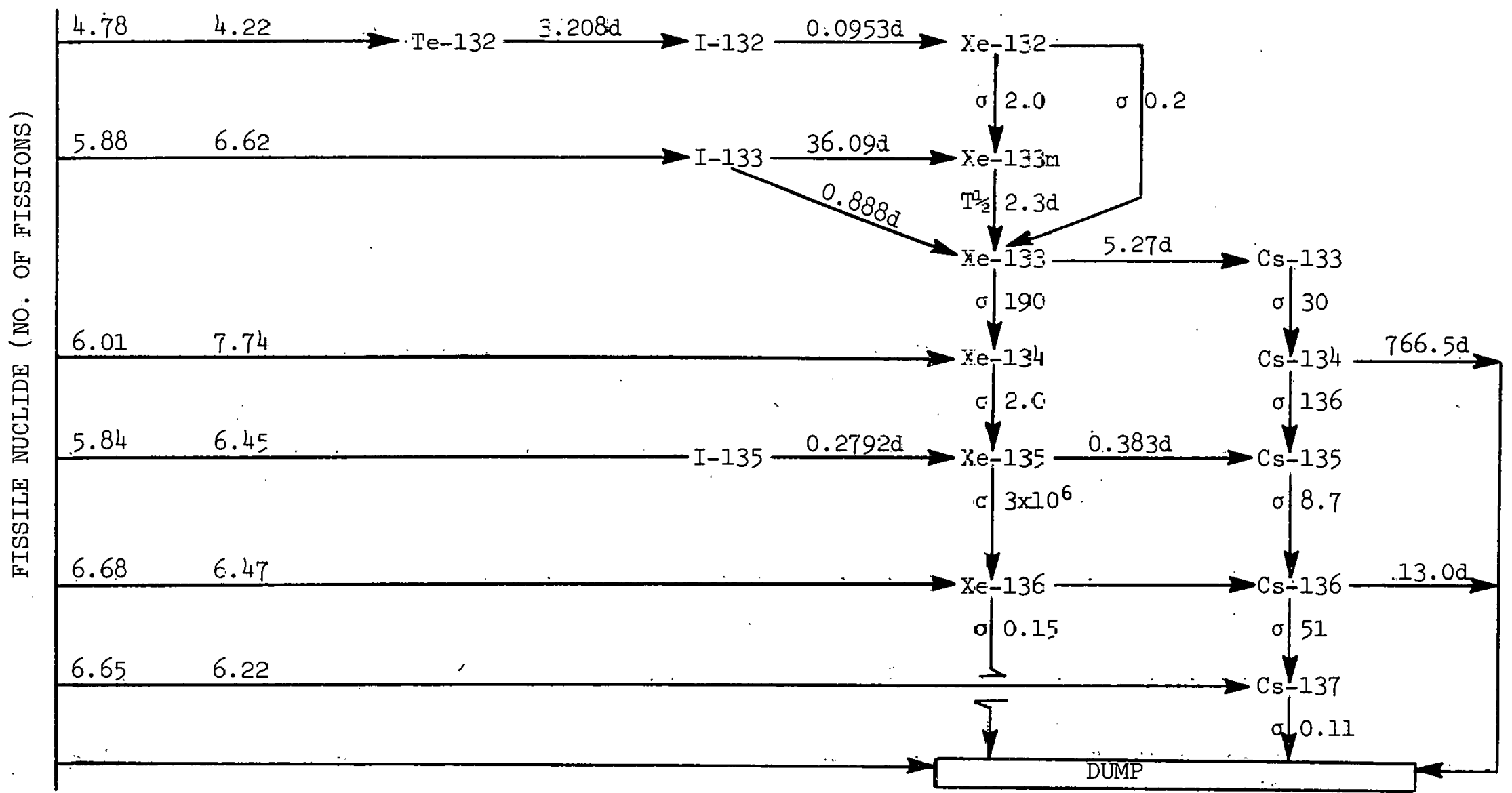

F-gure 1. COMPUTER PROGRAM SCHEMPTIC FOR. BUI-IUP IND BURNOUT OF FISSION PRODUCT CESIIM 
Table III. THERMAI FISSION YIELDS OF Cs-133 AND Cs-137 FOR U-233 FROM CAPSULE 6-2-4

Number of Fissions $=(4.138 \pm 0.045) \times 10^{19}(\operatorname{Ref} 3)$

$\underline{\text { Cs-133 }} \quad \underline{\text { Cs-137 }} \quad \begin{gathered}\text { Cs-137 } \\ \text { (radiometric)(Ref 3) }\end{gathered}$

Determined number

$2.470 \times 10^{18}$

$2.693 \times 10^{18}$

$2.801 \times 10^{18}$

of atoms

$\begin{array}{llll}\text { Std } \text { Dev }_{\text {avg }}(\mathrm{n}=3) & 0.022 \times 10^{18} & 0.010 \times 10^{18} & 0.056 \times 10^{18} \\ \begin{array}{l}\text { Atoms after correction } \\ \text { for neutron capture } \\ \text { and decay }\end{array} & 2.523 \times 10^{18} & 2.873 \times 10^{18} & 2.882 \times 10^{18} \\ \begin{array}{l}\text { Std Dev, \% (includes } \\ \text { estimated uncertainties }\end{array} & 0.94 & 0.63 & \\ \text { in correction factors } \\ \text { for neutron capture } \\ \text { and radioactive decay) }\end{array}$

Percent fission yield

6.10

6.94

6.96

Sta Dev

$0.08_{8}$

$0.08_{7}$

0.16

Std Dev, \%

1.4

1.2

2.3 
Table IV. THERMAL FISSION YIELDS OF Cs-133 AND

Cs-137 FOR U-233 FROM CAPSULE 6-4-2

Number of Fission $=(3.786 \pm 0.059) \times 10^{19}($ Ref 4$)$

\begin{tabular}{|c|c|c|c|}
\hline & Cs-133 & Cs -137 & $\begin{array}{c}\text { Cs-137 } \\
\text { (radiometric) (Ref 4) }\end{array}$ \\
\hline $\begin{array}{l}\text { Determined number } \\
\text { of atoms }\end{array}$ & $2.283 \times 10^{18}$ & $2.445 \times 10^{18}$ & $2.482 \times 10^{18}$ \\
\hline Std Dev ${ }_{\text {avg }}(n=4)$ & $0.004 \times 10^{18}$ & $0.010 \times 10^{18}$ & $0.049 \times 10^{18}$ \\
\hline $\begin{array}{l}\text { Atoms after correction } \\
\text { rur ueution capturc } \\
\text { and decay }\end{array}$ & $2.302 \times 10^{18}$ & $2.611 \times 10^{18}$ & $2.532 \times 10^{18}$ \\
\hline $\begin{array}{l}\text { Std Dev, \% (includes } \\
\text { estimated uncertainties } \\
\text { in correction factors } \\
\text { for neutron capture and } \\
\text { radioactive decay) }\end{array}$ & 0.35 & 0.50 & 1.97 \\
\hline Percent fission yield & 6.08 & 6.90 & 6.69 \\
\hline Sta Dev & $0.09_{8}$ & 0.11 & 0.17 \\
\hline Std Dev, \% & 1.6 & 1.6 & 2.5 \\
\hline
\end{tabular}


Table V. THERMAL FISSION YIELDS OF Cs-133 AND Cs-137 FOR U-233 FROM CAPSULE 6-4-3

Number of Fissions $=(3.390 \pm 0.062) \times 10^{19}(\operatorname{Ref} 5)$

\begin{tabular}{|c|c|c|c|}
\hline & Cs-133 & Cs-137 & $\begin{array}{c}\text { Cs-137 } \\
\text { (radiometric) (Ref - 5) } \\
\end{array}$ \\
\hline $\begin{array}{l}\text { Determined number } \\
\text { of atoms }\end{array}$ & $1.954 \times 10^{18}$ & $2.117 \times 10^{18}$ & $2.188 \times 10^{18}$ \\
\hline Std Dev avg $(n=4)$ & $0.010 \times 10^{18}$ & $0.013 \times 10^{18}$ & $0.043 \times 10^{18}$ \\
\hline $\begin{array}{l}\text { Atoms after correction } \\
\text { for neutron capture } \\
\text { and decay }\end{array}$ & $1.968 \times 10^{18}$ & $2.262 \times 10^{18}$ & $2.239 \times 10^{18}$ \\
\hline $\begin{array}{l}\text { Std Dev, \% (includes } \\
\text { estimated uncertainties } \\
\text { in correction factors. } \\
\text { for neutron capture } \\
\text { and radioactive decay) }\end{array}$ & 0.59 & 0.69 & 1.95 \\
\hline Percent fission yield & 5.81 & 6.67 & 6.60 \\
\hline Std Dev & 0.11 & 0.13 & 0.17 \\
\hline Std Dev, \% & 1.9 & 1.9 & 2.6 \\
\hline
\end{tabular}


Table VI. THERMAL FISSION YIELDS OF Cs-133 AND Cs-137 FOR U-233 FROM CAPSULE 6-5-1

Number of Fissions $=(2.614 \pm 0.055) \times 10^{19}(\operatorname{Ref} 3)$

\begin{tabular}{|c|c|c|c|}
\hline & $\underline{C_{s}-133}$ & $\underline{\mathrm{Cs}-137}$ & $\begin{array}{c}\text { Cs-137 } \\
\text { (radiometric) (Ref 3.) }\end{array}$ \\
\hline $\begin{array}{l}\text { Determined number } \\
\text { of atoms }\end{array}$ & $1.67 .6 \times 10^{18}$ & $1.798 \times 10=8$ & $1.795 \times 10^{18}$ \\
\hline Std $^{\text {Dev }}{ }_{\text {avg }}(n=4)$ & $0.022 \times 10^{18}$ & $0.014 \times 10^{18}$ & $0.036 \times 10^{18}$ \\
\hline $\begin{array}{l}\text { Atoms afler correction } \\
\text { t'or nelutron capture } \\
\text { and decay }\end{array}$ & $1.686 \times 10^{18}$ & $1.916 \times 1.0^{18}$ & $1.857 \times 10^{18}$ \\
\hline $\begin{array}{l}\text { Std Dev, \% (includes } \\
\text { estimated uncertainties } \\
\text { in correction faclurs } \\
\text { for neutron capture } \\
\text { and radioactive decay) } \\
\end{array}$ & 1.35 & 0.82 & 2.00 \\
\hline Percont fission yield & 6.45 & $7 \cdot 33$ & 7.03 \\
\hline Std Dev & 0.16 & 0.16 & 0.20 \\
\hline Std Dev, \% & 2.5 & 2.2 & 2.9 \\
\hline
\end{tabular}


Table VII. THERMAL FISSION YIELDS OF Cs-133 AND

Cs-137 FOR U-235 FROM CAPSULE 6-2-2

Number of Fissions $=(4.142 \pm 0.022) \times 10^{19}(\operatorname{Ref} 6)$

\begin{tabular}{|c|c|c|c|}
\hline & $\mathrm{Cs}-133$ & $\mathrm{Cs}-137$ & $\begin{array}{c}\text { Cs-137 } \\
\text { (radiometric) (Ref 6) } \\
\end{array}$ \\
\hline $\begin{array}{l}\text { Determined number } \\
\text { of atoms }\end{array}$ & $2.739 \times 10^{18}$ & $2.433 \times 10^{18}$ & $2.47 .7 \times 10^{18}$ \\
\hline Std Dev ${ }_{\text {avg }}(n=3)^{a}$ & $0.008 \times 10^{18}$ & $0.0076 \times 10^{18}$ & $0.049{ }_{5} \times 10^{18}$ \\
\hline $\begin{array}{l}\text { Atoms after correction } \\
\text { for neutron capture } \\
\text { and decay }\end{array}$ & $2.782 \times 10^{18}$ & $2.595 \times 10^{18}$ & $2.601 \times 10^{18}$ \\
\hline $\begin{array}{l}\text { Std Dev, \% (includes } \\
\text { estimated uncertainties } \\
\text { in correction factors } \\
\text { for neutron capture } \\
\text { and radioactive decay) }\end{array}$ & 0.41 & 0.43 & 2.00 \\
\hline Percent fission yiela & 6.72 & 6.27 & 6.28 \\
\hline Std Dev & 0.045 & 0.043 & 0.13 \\
\hline Std Dev, \% & 0.7 & 0.7 & 2.1 \\
\hline
\end{tabular}

a One sample was inatvertently lost during the chemical separation. 
Table VIII. THERMAL FISSION YIELDS OF Cs-133 AND

Cs-137 FOR U-235 FROM CAPSULE 6-4-1

Number of Fissions $=(2.839 \pm 0.032) \times 10^{19}(\operatorname{Ref} 7)$

\begin{tabular}{|c|c|c|c|}
\hline & $\mathrm{C} 3-133$ & Cs-137 & $\begin{array}{c}\text { Cs-137 } \\
\text { (radiometric) (Ref } 7) \\
\end{array}$ \\
\hline $\begin{array}{l}\text { Determined number } \\
\text { of atoms }\end{array}$ & $1.889 \times 10^{18}$ & $1.668 \times 10^{18}$ & $1.738 \times 10^{18}$ \\
\hline Std Dev ${ }_{\text {avg }}(n=4)$ & $0.006 \times 10^{18}$ & $0.006_{6} \times 10^{18}$ & $0.034 \times 10^{18}$ \\
\hline $\begin{array}{l}\text { Atoms after correction } \\
\text { for neutron capture } \\
\text { and decay }\end{array}$ & $1.905 \times 10^{18}$ & $1.782 \times 10^{18}$ & $1.765 \times 10^{18}$ \\
\hline $\begin{array}{l}\text { Std Dev, \% (includes } \\
\text { estimated uncertainties } \\
\text { in correciton factors } \\
\text { for neutron capture } \\
\text { and radioactive decay) }\end{array}$ & 0.44 & 0.50 & 1.98 \\
\hline Percent fission yield & 6.71 & 6.28 & 6.22 \\
\hline Std Dev & $0.08_{1}$ & 0.078 & 0.14 \\
\hline Std Dev, \% & 1.2 & 1.2 & 2.2 \\
\hline
\end{tabular}


Table IX. THERMAL FISSION YIELDS OF Cs-133 AND

Cs-137 FOR U-235 FROM CAPSULE 6-6-2

Number of Fissions $=(2.201 \pm 0.030) \times 10^{19}($ Ref 5)

\begin{tabular}{|c|c|c|c|}
\hline & $\mathrm{Cs}-133$ & $\underline{C s-137}$ & $\begin{array}{c}\text { Cs }-137 \\
\text { (radiometric)(Ref 5) } \\
\end{array}$ \\
\hline $\begin{array}{l}\text { Determined number } \\
\text { of atoms }\end{array}$ & $1.493 \times 10^{18}$ & $1.311 \times 10^{18}$ & $1.340 \times 10^{18}$ \\
\hline Std Dev $_{\text {avg }}(n=3)$ & $0.019 \times 10^{18}$ & $0.005_{8} \times 10^{18}$ & $0.026 \times 10^{18}$ \\
\hline $\begin{array}{l}\text { Atoms after correction } \\
\text { for neutron capture } \\
\text { and decay }\end{array}$ & $1.504 \times 10^{18}$ & $1.391 \times 10^{18}$ & $1.365 \times 10^{18}$ \\
\hline $\begin{array}{l}\text { Std Dev, \% (includes } \\
\text { estimated uncertainties } \\
\text { in correction factors } \\
\text { for neutron capture } \\
\text { and radioactive decay) }\end{array}$ & 1.28 & 0.53 & 1.95 \\
\hline Percent fission yield & 6.83 & 6.32 & 6.20 \\
\hline Std Dev & 0.13 & 0.09 & 0.15 \\
\hline Std Dev, \% & 1.9 & 1.5 & 2.4 \\
\hline
\end{tabular}




\section{ABSOLUTE THERMAL FISSION YIELDS \\ OF STABLE ZIRCONIUM ISOTOPES FOR U-233 AND U-235}

The absolute thermal fission yields of $\mathrm{Zr}-91,-92,-93,-94$, and -96 were determined for four U-233 and three U-235 capsules.

The irradiation histories and dissolution of the U-233 and U-235 capsules were the same as discussed in the previous section.

CHEMICAL SEPARATION OF ZIRCONIUM, S. F. Marsh, M. E. Kussy

The zirconium was separated carrier-free by a thorium iodate coprecipitation method (I). Potassium, leached from glassware, interferes with the mass spectrometric measurement. For this reason, a polyethylene tube is used for the final, anion exchange separation step, and polypropylene ware is used for the final evaporation just prior to the mass spectrometer measurement. The procedure is detailed in Appendix II.

MASS SPECTROMETRIC ANALYSIS OF ZIRCONIUM, R. M. Abernathey, L. W. Buttars, R. E. Mc $\Lambda$ tee, R. A. Nielsen, G. D. Workman

Evaporation of the zirconium samples from dilute hydrochloric acid onto a rhenium filament proved satisfactory for a triple filament source. 'The measured ion species was ' $\mathrm{rO}^{\prime}$.

'I'he mass spectrometer was a Nuclide Corporation, TDD-1, tandem, 12-in., $90^{\circ}$ instrument. Details of the instrument and its various detection systems have been reported (2). For zirconium, the 20-stage electron multiplier, electrometer, strip chart detection system was used. Mass discrimination was established by comparing results from a synthetic mixture of $\mathrm{Zr}-90$ and $\mathrm{Zr}-96$ to those obtained from the same samples with the nondiscriminating Faraday Cage detection system. The Faraday Cage results are compared to Nuclear Data Sheets (8) values in Table X.

The procedure for the mass spectrometric analysis of zirconium is detailed in Appendix II.

FISSION YIELDS OF THE ZIRCONIUM ISOTOPES FOR U-233, M. E. Kussy, F. L. Lisman, F. W. Spraktes

The absolute thermal fission yields of $\mathrm{Zr}-91,-92,-93,-94$, and -96 were determined on each of the four irradiated U-233 capsules. 
Table $\mathrm{X}$. COMPARISON OF ISOTOPIC

DISTRIBUTION OF NATURAL ZIRCONIUM

\section{Isotope}

90

91

92

94

96
Value, Atom Percent This Work (a) NDS

$51.427 \pm 0.002 \quad 51.46$

$11.208 \pm 0.008 \quad 11.23$

$17.130 \pm 0.009 \quad 17.11$

$17.431 \pm 0.002 \quad 17.40$

$2.804 \pm 0.005-2.80$

\footnotetext{
(a) Error is expressed as the standard deviation of the average for duplicate determinations.
} 
Eight 1-ml aliquots (four spiked with known amounts of $\mathrm{Zr}-90$ and four without spike) were analyzed from each dissolver solution. The results and calculated fission yields are summarized in Tables XI thru XIV. The calculation of the number of atoms of each zirconium isotope is detailed in Appendix II. The number of U-233 fissions was calculated as described in the previous section. The determined number of fissions for each U-233 capsule and the appropriate references are given in Tables XI through XIV.

As in the case of the thermal fission yields of the cesium isotopes, corrections for the buildup and burnout of the zirconium isotopes were based on a computer program which simulated the irradiation history of the samples. A schematic di.agram ne the program for the buildup dul burnoute of zintanllum is given in figure 2 .

FISSIUN YIELDS OF THE ZIRCONIUM ISOTOPES FOR U-235, M. E. KusSy, F. L. Lisman, F. W. Spraktes

The absolute thermal fission yields of $\mathrm{Zr}-91,-92,-93,-94$, and -96 were determined on each of the three irradiated U-235 capsules.

Eight I-ml aliquots (four spiked with known amounts of $\mathrm{Zr}-90$ and four without spike) were analyzed from each dissolver solution. The analysis results and calculated fission yields are summarized in Tables XV through XVII.

As in the case of the thermal fission yields of the zirconium isotopes for U-233, corrections for the buildup and burnout. nf the zirconium isotopes were based on a computer program which simulated the irradiation history of the samples. 


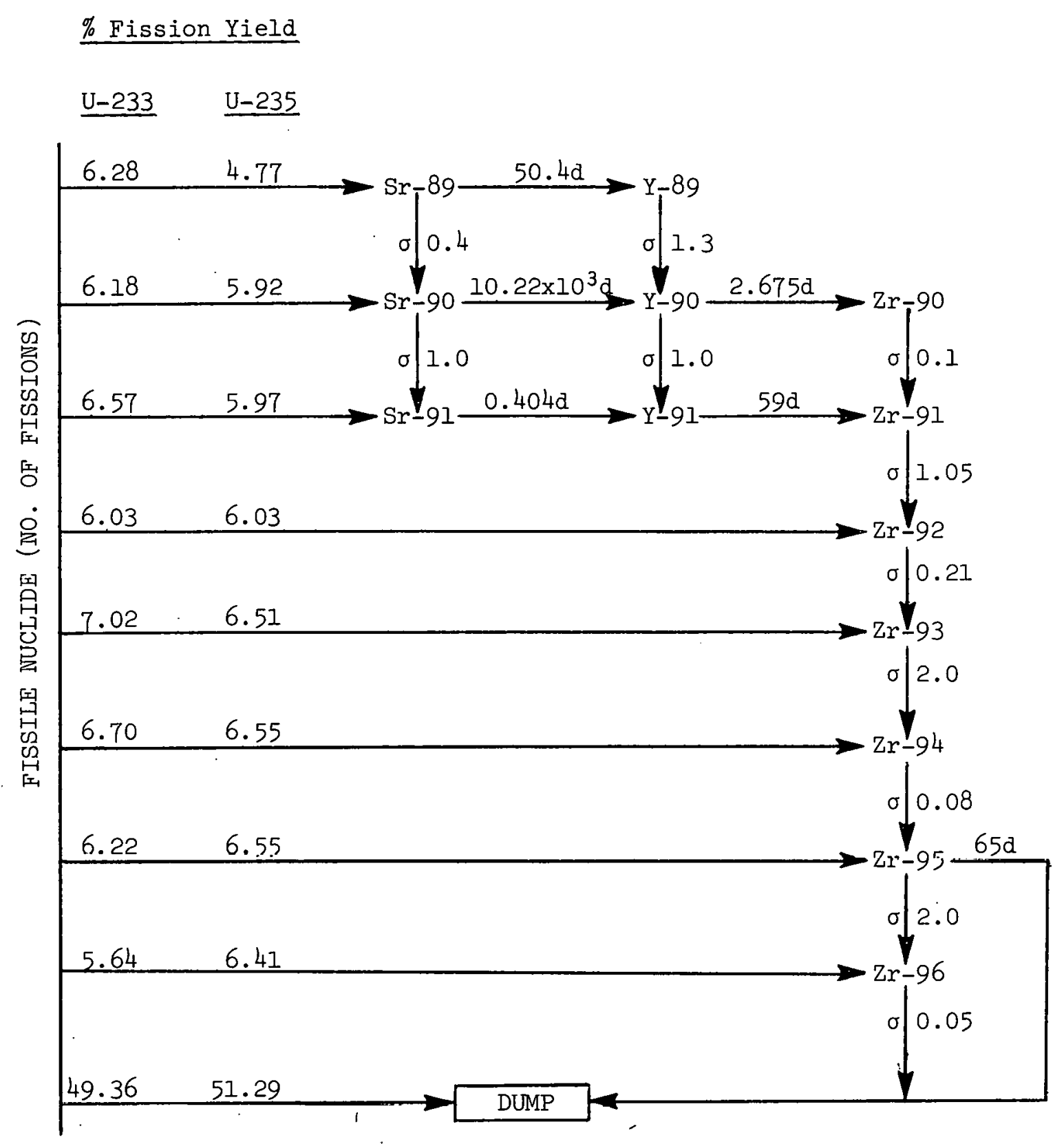

Figure 2. COMPUTER PROGRAM SCHEMATIC FOR BUILDUP AND BURNOUT OF FISSION PRODUCT ZIRCONIUM 
Table XI. THERMAL FISSICN YIELDS OF STABLE ZIFCONIUM ISOTOPES FOR U-233 FROM CAPSULE 6-2-L

Number of Fissions $=(4.138 \pm 0.045) \times 10^{19}(R \in f 3)$

Zr-91

$\begin{array}{ll}2.715 \times 10^{18} & 2.756 \times 10^{18} \\ 0.013 \times 10^{18} & 0.013 \times 10^{18} \\ 2.714 \times 10^{18} & 2.756 \times 10^{18}\end{array}$

0.49

0.49

\begin{abstract}
Atoms after correction for neutron capture and decay

Std Dev, \% (includes estimated uncertainties in correction factors for neutron capture and radioactive decay)

Determined number of atoms

Std Dev avg $(n=4)$
\end{abstract}

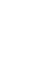

Percent fission yielz

Std Dev

Std Dev, \%

\subsection{6 \\ 0.078 \\ 1.19}

$\underline{\mathrm{Zr}-93}$

Zr-94

$\underline{\mathrm{Zr}-96}$

\section{$2.921 \times 10^{18}$}

$0.014 \times 10^{1 \varepsilon}$

$2.863 \times 10^{18}$

$2.434 \times 10^{18}$

$2.924 \times 10^{18}$

$0.014 \times 10^{18}$

$0.012 \times 10^{18}$

$2.861 \times 10^{18}$

$2.433 \times 10^{18}$

0.49

0.49

0.52 
Table XII. THERMAL FISSION YIEIDS OF STABLE ZIRCONIUM ISOTOPES FOR U-233 FROM CAPSULE 6-4-2

Number of Fissions $=(3.786 \pm 0.059) \times 10^{19}(\operatorname{Ref} 4)$

$\underline{Z r-91} \quad \underline{Z r-92} \quad \underline{Z r-93} \quad \underline{Z r-94} \quad \underline{Z r-96}$

Determined number of atoms

$2.494 \times 10^{18}$

$2.561 \times 10^{18}$

$2.711 \times 10^{18}$

$2.632 \times 10^{18}$

$2.215 \times 10^{18}$

Std Dev avg $(n=4)$

$0.011 \times 10^{18}$

$0.011 \times 10^{18}$

$0.012 \times 10^{18}$

$0.011 \times 10^{18}$

$0.010 \times 10^{18}$

$2.529 \times 10^{18}$

$2.561 \times 10^{18}$

$2.712 \times 10^{18}$

$2.632 \times 10^{18}$

$2.215 \times 10^{18}$

neutron capture and decay

Std Dev, \% includes estimated uncertainties in correction factors for neutron capture and radioactive decay)
0.43

0.43
0.43

0.46

$\begin{array}{lllll}6.68 & 6.76 & 71.6 & 6.95 & 5.85 \\ 0.11 & 0.11 & 0.12 & 0.11 & 0.096 \\ 1.7 & 1.6 & 1.6 & 1.6 & 1.6\end{array}$


Table XIII. THARMAL FISSION YIELDS OF STABLE ZIRCONIUM ISOTOPES FOR U-233 FROM CAFSUL $\Xi$ 6-4-3

Number of Fissions $=(3.390 \pm 0.062) \times 10^{19}(\operatorname{Ref} 5)$

\begin{tabular}{|c|c|c|c|c|c|}
\hline & $3 r-91$ & $\mathrm{Zr}-92$ & $\mathrm{Zr}-93$ & $\mathrm{Zr}-94$ & $\mathrm{Zr}-96$ \\
\hline Determined number of atoms & $2.50 \times 10^{18}$ & $2.183 \times 10^{18}$ & $2.308 \times 10^{18}$ & $2.256 \times 10^{18}$ & $1.888 \times 10^{18}$ \\
\hline Std Dev $_{\text {avg }}(n=3)$ & $0.510 \times 10^{18}$ & $0.010 \times 10^{18}$ & $0.011 \times 10^{18}$ & $0.012 \times 10^{18}$ & $0.009 \times 10^{18}$ \\
\hline $\begin{array}{l}\text { Atoms after correction for } \\
\text { neutron capture and decay }\end{array}$ & $2.165 \times 10^{18}$ & $2.183 \times 10^{18}$ & $2.308 \times 10^{18}$ & $2.256 \times 10^{18}$ & $1.887 \times 10^{18}$ \\
\hline $\begin{array}{l}\text { Std Dev, \% (includes estimated } \\
\text { uncertainties in correction } \\
\text { factors for neutron capture } \\
\text { and radioactive decay) }\end{array}$ & 0.49 & 0.47 & 0.47 & 0.52 & 0.47 \\
\hline
\end{tabular}

\begin{tabular}{lllccc}
\hline Percent fission yieid & 6.38 & 6.44 & 6.81 & 6.65 & 5.57 \\
Std Dev & 0.12 & 0.12 & 0.13 & 0.12 & 0.10 \\
Std Dev, \% & 1.9 & 1.9 & 1.9 & 1.9 & 1.9
\end{tabular}


Table XIV. THERMAL FISSION YIELDS OF STABLE ZIRCONIUM ISOTOPES FOR U-233 FROM CAPSULE 6-5-1

Number of Fissions $=(2.614 \pm 0.055) \times 10^{19}($ Ref 3$)$

$\underline{Z r-91}$

Determined number of atoms

Std $\operatorname{Dev}_{\text {avg }}(n=3)^{a}$

Atoms after correction for

neutron capture and decay

Std Dev, \% (includes estimated uncertainties in correction

factors for neutron capture

and radioactive decay

$1.820 \times 10^{18}$
$0.012 \times 10^{18}$
$1.820 \times 10^{18}$

0.64 $\underline{\text { Zr-93 }}$

$1.850 \times 10^{18}$

$0.012 \times 10^{18}$

$1.850 \times 10^{18}$

0.64

0.65
$1.969 \times 10^{18}$

$0.013 \times 10^{18}$

$1.969 \times 10^{18}$

$1.913 \times 10^{18}$

$0.012 \times 10^{18}$

$1.912 \times 10^{18}$

$1.611 \times 10^{18}$

.64
Percent fission yield

Std Dev

Std Dev, \%

\subsection{6}

0.15

2.2

7.07

0.15

2.2

7.53

0.16

2.2

Zr-96

$1.611 \times 10^{18}$

$0.010 \times 10^{18}$

a One sample was inadvertently lost during the chemical separation. 
Table XV. THERMAL FISSION YIELDS OF STABLE: ZIRCONIUM ISOTOPES FOR U-235 FROM CAPSULE 6-2-2

Number of Fissions $=(4.142 \pm 0.022) \times 10^{19}(\operatorname{Ref} 6)$

$\underline{\underline{Z} r-91}$

Determined number of atoms

Std Dev $\operatorname{avg}_{(n=4)}$

Ators after correction for neutron capture and decay

Std Dev, \% (includes estimated uncertainties in correction factors for neutron capture and radioactive decay)
$2.445 \times 10^{18}$
$0.0112 \times 10^{18}$
$2.4 L .4 \times 10^{18}$

0.49

$\underline{\mathrm{Zr}-93}$

$\underline{Z r-94}$

Zr-96

$$
\text { Zr-92 }
$$

$$
2.469 \times 10^{18}
$$

$0.012 \times 10^{18}$

$2.629 x=0^{18}$

$2.652 \times 10^{18}$

$2.584 \times 10^{18}$

$0.013 \times 10^{18}$

$0.013 \times 10^{18}$

$0.013 \times 10^{18}$

$2.469 \times 10^{18}$

$2.631 \times 10^{18}$

$2.650 \times 10^{18}$

$2.584 \times 10^{18}$

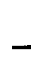

Percent fission yield

5.90

5.96

6.35

6.40

6.24

Std Dev

0.042

0.043

0.046

0.046

0.045

Std Dev, \%

0.7

0.7

0.7

0.7

0.7 
Table XVI. THERMAL FISSION YIELDS OF STABLE ZIRCONIUM -SOTOPES FOR U-235 FROM CAPSULE 6-4-1

Number of Fissions $=(2.839 \pm 0.032) \times 10^{19}(\operatorname{Ref} 7)$

$\underline{Z r-91} \underline{Z r-92} \quad \underline{Z r-93} \quad \underline{Z r-94} \quad \underline{Z r-96}$

Determined number of atoms

$1.653 \times 10^{18} \quad 1.682 \times 10^{18}$

Std Dev avg $(n=4)$

Atoms after correction for neutron capture and decay

Std Dev, \% (亡̈ncludes estimated uncertainties in correction

- factors for neutron capture and radioactive decay)

\section{Percent fission yield}

Stả Dev

Sta Dev, \%

$\begin{array}{lll}5.90 & 5.92 & 6.31 \\ 0.077 & 0.07_{6} & 0.08_{1} \\ 1.3 & 1.3 & 1.3\end{array}$

$1.791 \times 10^{18}$

$1.832 \times 10^{18}$

$1.769 \times 10^{18}$

$0.010 \times 10^{18} \quad 0.010 \times 10^{18}$

$0.011 \times 10^{18}$

$0.011 \times 10^{18}$

$0.013 \times 10^{18}$

$1.675 \times 10^{18}$

$1.682 \times 10^{18}$

$1.792 \times 10^{18}$

$1.831 \times 10^{18}$

0.66

0.62

0.62

0.59

0.76

$\begin{array}{lll}6.31 & 6.45 & 6.23 \\ 0.08_{1} & 0.08_{2} & 0.08_{5} \\ 1.3 & 1.3 & 1.4\end{array}$

$1.768 \times 10^{18}$ 
Table XVII. THERMAL FISSION YIELDS OF STABLE ZIRCONIUM ISOTOPES FOR U-235 FROM CAPSULE 6-6-2

$$
\text { Number of fissions }=(2.201 \pm 0.030) \times 10^{19}(\operatorname{R\in f} 5)
$$

$\underline{Z r-9=} \quad \underline{Z r-92} \quad \underline{Z r-93} \quad \underline{Z r-94} \quad \underline{Z r-96}$

\begin{tabular}{|c|c|c|c|c|c|}
\hline Determined number of atoms & $1.269 x=0^{18}$ & $1.313 \times 1 C^{18}$ & $1.396 \times 10^{18}$ & $1.412 \times 10^{18}$ & $1.370 \times 10^{18}$ \\
\hline Std Dev ${ }_{\text {avg }}(n=3)^{a}$ & $0.006 x_{-0}=18$ & $0.006 \times 10^{18}$ & $0.006 \times 10^{18}$ & $0.006 \times 10^{18}$ & $0.006 \times 10^{18}$ \\
\hline $\begin{array}{l}\text { Atoms after correcticn for } \\
\text { neutron capture and decay }\end{array}$ & $1.298 \times 10^{18}$ & $1.313 \times 10^{18}$ & $1.396 \times 10^{18}$ & $1.412 \times 10^{18}$ & $1.370 \times 10^{18}$ \\
\hline $\begin{array}{l}\text { Std Dev, \% (includes estimated } \\
\text { uncertainties in correction } \\
\text { factors for neutron capture } \\
\text { and radioactive decay) }\end{array}$ & 0.55 & 0.43 & 0.43 & 0.45 & 0.47 \\
\hline
\end{tabular}

\begin{tabular}{|c|c|c|c|c|c|}
\hline Percent fission yield & 5.90 & 5.97 & 6.34 & 6.42 & 6.22 \\
\hline Std Dev & $0.08_{7}$ & $0.08_{7}$ & $0.09_{2}$ & $0.09_{3}$ & $0.09_{1}$ \\
\hline Std Dev, \% & 1.5 & 1.4 & 1.4 & 1.4 & 1.5 \\
\hline
\end{tabular}

a One sample was inadvertently lost during the chemical separation: 


\section{REFERENCES}

1. Maeck, W. J., Rein, J. E., Editors, Burnup Determination of Nuclear Fuels: 1964 Annual Report, IDO-14656 (1965).

2. Maeck, W. J., Abernathey, R. M., Rein, J. E., Editors, Burnup Determination of Nuclear Fuels: Project Report for the Quarter October I December 31, 1965, ID0-14676 (1966).

3. Maeck, W. J., Rein, J. E., Editors, Burnup Determination of Nuclear Fuels: Project Report for the Quarter April 1 - June 30, 1966, ID0-14681 (1967).

4. Maeck, W. J., Rein, J. E., Editors, Burnup Determination of Nuclear Fuels: Project Report for the Quarter April 1 - June 30, 1965, IDO-14663 (1965).

5. Maeck, W. J., Rein, J. E., Editors, Burnup Determination of Nuclear Fuels: Project Report for the Quarter July 1 - September 30, 1965, IDO-14667 (1965).

6. Lisman, F. L., Maeck, W. J., Foster, R. E., Jr., Rein, J. E., Burnup Determination of Nuclear Fuels: Project Report for the Quarter July 1 - September 30, 1966, IN-1064 (1967).

7. Maeck, W. J., Rein, J. E., Editors, Burnup Determination of Nuclear Fuels: Project Report for the Quarter January 1 - March 31, 1965, IDO-14660 (1965).

8. Nuclear Data Sheets, Appendix 2, Relative Isotopic Abundances, National Academy of Sciences - National Research Council, Washington, D. C. 


\section{THIS PAGE}

\section{WAS INTENTIONALLY \\ LEFT BLANK}


APPENDIX I

PROCEDURE FOR THE SEPARATION

AND MASS SPECTROMETRIC ANALYSIS

OF FISSION PRODUCT CESIUM

R. E. Foster, Jr., R. M. Abernathey, F. L. Lisman 


\section{THIS PAGE}

\section{WAS INTENTIONALLY \\ LEFT BLANK}




\section{PREPARATION AND STANDARDIZATION \\ OF NATURAL CESIUM SPIKE}

Approximately $1 \mathrm{~g}$ of "Specpure" cesium chloride was heated in a muffle furnace at $500^{\circ} \mathrm{C}$ for $16 \mathrm{hr}$, then weighed and dissolved in approximately 1 liter (by weight) of quartz-distilled water. Three 100-g aliquots were gravimetrically analyzed by fuming to the sulfate with sulfuric acid. The determined concentration was $1.0094 \mathrm{mg} \mathrm{Cs} / \mathrm{g}$ solution with a relative standard deviation for the average of $0.18 \%$.

Weight aliquots containing approximately $5 \mathrm{mg}$ of $\mathrm{Cs}$ were transferred to glass ampoules which were flame sealed. When used, the entire contents of an ampoule were diluted approximately 1000 fold (by weight) and weight a.liquots were taken.

\section{CHEMICAL SEPARATION}

1. Pipet approximately $1 \mathrm{ml}$ of Cs-133 spike solution into a tared 15-ml polypropylene tube and reweigh the tube.

2. Accurately pipet a l-ml aliquot of the dissolver solution into the 15-ml polypropylene tube.

3. Add one drop of quartz-distilled 4. $5 \mathrm{M} \mathrm{H}_{2} \mathrm{SO}_{4}$ and stir the solution.

4. Add one drop of methyl red indicator solution.

5. Add quartz-distilled $\mathrm{NH}_{4} \mathrm{OH}$ dropwlse until the solution turns yellow.

6. Centrifuge.

7. Transfer the supernatant solution to a clean 15-ml polypropylene tube.

8. Add $1 \mathrm{ml}$ of conc quartzdistilled $\mathrm{HNO}_{3}$.

9. Evaporate to approximately 0.1 $\mathrm{ml}$ with a heat lamp.
This establishes the amount of $\mathrm{Cs}-133$ spike.

Use a calibrated pipet.

A vortex mixer is satisfactory.
Discard any precipitate which usually is a metal hydroxide(s) forming from fuel components.
During the evaporation, $\mathrm{NH}_{4} \mathrm{Cl}$ may precipitate, If so, add an additional drop of conc $\mathrm{HNO}_{3}$ and continue the evaporation. 
1. Prepare a canoe-shaped filament from high purity, 1- x 30-mil rhenium ribbon, and vacuum bake it for $1 \mathrm{hr}$ at $4 \mathrm{~A}$ at a pressure of $1 \times 10^{-6}$ torr. Assemble the sample filament in the center (ionizing) position.

2. Using a new, freshly cleaned, disposable glass pipet, transfer the solution from step 9 (previnus sestion) to the filament. Evaporate the solution by passing 1.2 A through the filament.

3. Mount the filament holder on - the ion source carriage and insert the carriage into the vacuum lock.

4. Adjust the filament current to 0.6 to $0.8 \mathrm{~A}$ and locate the major isotope beam by reference to the mass-vs-DVM (accelerating voltage) curve for the magnetic field in use. Adjust the source voltage divider controls for the maximum beam. Make a rapid voltage scan in both directions to verify the mass identification.

5. Insert the Faraday Cage collector and increase the filament current to obtain an ion current of $3 \times 10^{-11} \mathrm{~A}$. Scan the spectrum magnetically in both directions, recording the sensitivity settings used to give near full-scale peak heights. Obtain three charts of $4 \frac{1}{2}$ double scans.
Most of the trace cesium and barium impurities are volatilized

Allow about. I-min pumping time at each lock stage.

Use the electron multiplier. Keep the J2 setting low, the J10 setting maximum, and the J4-J5 setting near center. The source may need to be rotated to get J4-J5 centered with the maximum beam. 
6. Graphically interpolate by drawing lines on the chart which connect the tops of the successive peaks of each isotope. Draw vertical lines on the chart at each turnaround in the scans, and take peak height readings at the intersections of these lines with those connecting the peak tops. Sum. the readings for each isotope.
Use the same number of readings in each sum. If the atom percent of an individual isotope is desired, it is given by: atom $\% \mathrm{Cs}^{\mathrm{A}}=$ $100 \frac{\sum \text { peak heights }}{\sum\left(\sum \text { peak heights }\right)}$

CALCULATIONS

Let $R_{\text {ff }}$ be the atom ratio of $\mathrm{Cs}_{\mathrm{s}}-133$ to $\mathrm{Cs}-137$ in the spiked fission product sample. Then:

$$
R_{s f}=\frac{N_{s}^{3}+N_{f}^{3}}{N_{f}^{7}}
$$

where: $\mathbb{N}_{\mathrm{S}}^{3}=$ number of spike Cs-133 atoms in the sample.

$$
\begin{aligned}
N_{f}^{3} & =\text { number of fission product } \mathrm{Cs}-133 \text { atoms in the sample. } \\
\mathrm{N}_{\mathrm{f}^{\prime}}^{7} & =\text { number of fission product } \mathrm{Cs}-137 \text { atoms in the sample. }
\end{aligned}
$$

To eliminate the $\mathbb{N}_{f}^{3}$ term from equation (I), let $R_{f}$ be the atom ratio of fission product $\mathrm{Cs}-133$ to $\mathrm{Cs}-137$ in an unspiked fission product sample. Then:

$$
R_{f}=\frac{N_{f}^{3}}{N_{f}^{7}}
$$

and

$$
\mathrm{N}_{\mathrm{f}}^{3}=\mathrm{R}_{\mathrm{f}} \mathrm{N}_{\mathrm{f}}^{7}
$$


Substituting for $\mathrm{N}_{\mathrm{f}}^{3}$ in equation (I) yields.

$$
R_{s f}=\frac{N_{s}^{3}+R_{f} N_{f}^{7}}{N_{f}^{7}}
$$

and

$$
N_{f}^{7}=\frac{N_{s}^{3} V_{d}}{\left(R_{s f}-R_{f}\right) V_{x}}
$$

where: $v_{\mathrm{d}}=$ volume of the dissolver solution

$$
\mathrm{V}_{\mathrm{x}}=\text { volume of sample aliquot }
$$

Normally $K_{f}$ is obtained on four unspiked aliquots and the average $\left(\bar{R}_{f}\right)$ is used to calculate $\mathrm{N}_{\mathrm{f}}^{7}$. Thus:

$$
N_{f}^{7}=\frac{N_{s}^{3} V_{d}}{\left(R_{s f}-\bar{R}_{f}\right) V_{x}}
$$

The number of fission product $\mathrm{Cs}-133$ atoms is:

$$
\mathbb{N}_{f}^{3}=\bar{R}_{f}^{i N_{f}^{7}}
$$

ERROR PROPAGATION FOR Cs-137

The number of Cs-137 atoms, by equation III of the previous section is:

$$
N_{f}^{7}=\frac{N_{s}^{3} V_{d}}{\left(R_{s f}-\bar{R}_{f}\right) V_{x}}
$$

Reported values are the average of several determinations: .

$$
\vec{N}_{f}=\frac{\sum_{i=1}^{n} N_{f_{i}}^{7}}{n}
$$


where: $\overrightarrow{\mathbb{N}_{f}}=$ average number of Cs-137 atoms

$$
\begin{aligned}
& \mathrm{N}_{\mathrm{f}_{i}}^{7}=\text { number of } \mathrm{Cs}-137 \text { atoms in the } i^{\text {th }} \text { sample. } \\
& \mathrm{n}=\text { number of determinations. }
\end{aligned}
$$

or:

$$
\overrightarrow{N_{f}}=\sum_{i=1}^{n} \frac{N_{s_{i}}^{3} v_{d}}{\left(R_{s f_{i}}-R_{f_{i}}\right) v_{x}}
$$

$V_{d}$ and usually $v_{x}$ are the same for all samples. Also $\bar{R}_{f}$ is the same for all determinations on a given capsule. Thus:

$$
\overline{\mathrm{N}}_{f}=\frac{\left(\sum_{i=1}^{n} \frac{\mathrm{N}_{\mathrm{s}_{i}}^{3}}{\left(\mathrm{R}_{\mathrm{sf}_{i}}-\overline{\mathrm{R}}_{f^{\prime}}\right)}\right) \frac{\mathrm{v}_{d}}{\mathrm{v}_{\mathrm{x}}}}{\mathrm{n}}
$$

The variance of $\overline{\mathrm{N}}_{f}^{7}$ is then given approximately. by:

$$
\begin{aligned}
\sigma^{2} \overline{\mathrm{N}}_{f}^{7}= & \sum_{i=1}^{n}\left(\frac{\partial \vec{N}_{f}^{7}}{\partial N_{i^{\prime}}^{3}}\right)^{2} \sigma^{2} \mathbb{N}_{s_{i}}^{3}+\sum_{i=1}^{n}\left(\frac{\partial \vec{N}_{f}^{7}}{\partial R_{s f_{i}}}\right)^{2} \sigma^{2} R_{s f_{i}}+\left(\frac{\partial \vec{N}_{f}^{7}}{\partial \bar{R}_{f}}\right)^{2} \sigma^{2} \bar{R}_{f} \\
& +\left(\frac{\partial \bar{N}_{f}^{7}}{\partial v_{d}}\right)^{2} \sigma^{2} v_{d}+\left(\frac{\partial \bar{N}_{f}^{7}}{\partial v_{x}}\right)^{2} \sigma^{2} v_{x}+\text { (covariance terms) }
\end{aligned}
$$

The covariance terms are negligible.

and

$$
\frac{\partial \bar{N}_{f}^{7}}{\partial N_{\varepsilon_{i}}^{3}}=\frac{V_{d}}{n v_{x}},\left[\frac{1}{\left(R_{s f_{i}}-\bar{R}_{f}\right)}\right]
$$




$$
\begin{aligned}
& \frac{\partial \bar{N}_{f}^{7}}{\partial R_{s f_{i}}}=\frac{v_{d}^{*}}{n v_{x}}\left[\frac{-N_{s_{i}}^{3}}{\left(R_{s f_{i}}-\bar{R}_{f}\right)^{2}}\right] \\
& \frac{\partial \bar{N}_{f}^{7}}{\partial R_{f}^{\cdot}}=\frac{v_{d}}{n v_{x}}\left[\sum_{i=1}^{n} \frac{N_{s_{i j}}^{3}}{\left(R_{s f_{i}}-\bar{R}_{f}\right)^{2}}\right] \\
& \frac{\partial \bar{N}_{f}^{7}}{\partial v_{d}} \quad=\frac{1}{n v_{x}}\left[\sum_{i=1}^{n} \frac{N_{s_{i}}^{3}}{\left(R_{s f}-\bar{R}_{f}\right)}\right] \\
& \frac{\partial \bar{v}_{f}^{7}}{\partial v_{x}}=-\frac{v_{d}}{n v_{x}^{2}}\left[\sum_{i=1}^{n} \frac{N_{s_{i}^{3}}}{\left(R_{s f_{i}}-\bar{R}_{f}\right)}\right]
\end{aligned}
$$

or

$$
\begin{aligned}
\sigma^{2} \bar{N}_{f}^{7} & =\frac{1}{n^{2} v_{x}^{2}}\left\{v _ { d } ^ { 2 } \left[\sum_{i=1}^{n}\left[\frac{i}{\left(R_{s f_{i}}-\bar{R}_{f}\right)}\right]^{2} \sigma^{2} N_{i}^{3}\right.\right. \\
& +\sum_{i=1}^{n}\left[\frac{-N_{s}^{3}}{\left(R_{s f_{i}}-\bar{R}_{f}\right)^{2}}\right]^{2} \sigma^{2} R_{s f_{i}} \\
& +\left[\sum_{i=1}^{n} \frac{N_{s}^{3}}{\left(R_{s f_{i}}-\bar{R}_{f}\right)^{2}}\right]^{\sigma^{2} \bar{R}_{f}}
\end{aligned}
$$

36 


$$
\begin{aligned}
& \left.+\frac{1}{\mathrm{v}_{\mathrm{x}}^{2}}\left[\sum_{i=1}^{\mathrm{n}} \frac{\mathbb{N}_{s_{i}^{3}}^{3}}{\left(\mathrm{R}_{\mathrm{sf}_{i}}-\overline{\mathrm{R}}_{f}\right)}\right]^{2} \sigma^{2} \mathrm{v}_{\mathrm{x}}\right] \\
& +\left[\sum_{i=1}^{\mathrm{n}} \frac{\mathrm{N}_{\mathrm{s}_{i}}^{3}}{\left(\mathrm{R}_{\mathrm{sf}}-\overline{\mathrm{R}}_{\mathrm{f}}\right)}\right]^{2} \sigma^{2} \mathrm{v}_{\mathrm{d}}
\end{aligned}
$$

The variance $\sigma^{2} \bar{R}_{f}$ is obtained from multiple determinations on unspiked samples. The variance $\sigma^{2} R_{s f_{i}}$ is obtained by averaging the values of $\sigma^{2} R_{S f}$ determined from multiple scans on several spiked samples and $\mathrm{R}_{\text {sf }}$

then assumed to be the same from all samples from a given capsule. 
The number of Cs-133 atoms present is given by:

$$
N_{f_{i}}^{3}=N_{s_{i}}^{7} \bar{R}_{f}
$$

Reported values are the average of several determinations and:

$$
\begin{aligned}
& \bar{N}_{f}^{3}=\frac{\sum_{i=1}^{n} N_{f_{i}}^{7} \bar{R}_{f}}{n} \\
& \bar{N}_{\bar{I}}^{3}=\frac{v_{d}}{n V_{x}}\left[\sum_{i=1}^{n} \frac{\bar{R}_{f} N_{s}^{3}}{\left[R_{s f}-\bar{R}_{f}\right]}\right]
\end{aligned}
$$

The variance of $\mathrm{N}_{\mathrm{f}}^{3}$ is given approximately by:

$$
\begin{aligned}
\sigma^{2} \bar{N}_{f}^{3} & =\sum_{i=1}^{n}\left(\frac{\partial \bar{N}_{f}^{3}}{\partial R_{s f_{i}}}\right)^{2} \sigma^{2} R_{s f_{i}}+\sum_{i=1}^{n}\left(\frac{\partial \bar{N}_{f}^{3}}{\partial N_{s}^{3}}\right)_{i}^{2} \sigma^{2} N_{s_{i}}^{3} \\
& +\left(\frac{\partial \bar{N}_{f}^{3}}{\partial R_{f}}\right)^{2} \sigma^{2} R_{f}+\left(\frac{\partial \bar{N}_{f}^{3}}{\partial V_{d}}\right)^{2} \sigma^{2} v_{d}+\left(\frac{\partial \bar{N}_{f}^{3}}{\partial V_{x}}\right)^{2} \sigma^{2} v_{x} \\
& + \text { (covariance terms) }
\end{aligned}
$$

The covariance terms are negligible.

and:

$$
\frac{\partial \bar{N}_{i}^{3}}{\partial R_{s f_{i}}}=\frac{v_{a}}{n V_{x}}\left(\frac{-\bar{R}_{f} N_{i}^{3}}{\left[R_{s f_{i}}-\bar{R}_{f}\right]^{2}}\right)
$$




$$
\frac{\partial \bar{N}_{f}^{3}}{\partial N_{s_{i}}^{3}}=\frac{V_{d}^{2}}{n v_{x}}\left(\frac{\bar{R}_{f}}{\left[R_{s f_{i}}-\bar{R}_{f}\right]}\right)
$$

$$
\frac{\partial \bar{N}_{f}^{3}}{\partial R_{f}}=\frac{v_{d}}{n v_{x}} \quad\left[\sum_{i=1}^{n} \frac{R_{s f_{i}} N_{s}^{3}}{\left[R_{s f_{i}}-\bar{R}_{f}\right]^{2}}\right]
$$

$$
\begin{aligned}
& \frac{\partial \bar{N}_{f}^{3}}{\partial v_{d}}=\frac{1}{n v_{x}}\left[\sum_{i=1}^{n} \frac{\bar{R}_{f} N_{i}^{3}}{\left[R_{s f}-\bar{R}_{f}\right]}\right] \\
& \frac{\partial \bar{N}_{f}^{3}}{\partial v_{x}}=\frac{-v_{d}}{n v_{x}}\left[\sum_{i=1}^{n} \frac{\bar{R}_{f} N_{s}^{3}}{\left[R_{s f}-\bar{R}_{f}\right]}\right]
\end{aligned}
$$

and:

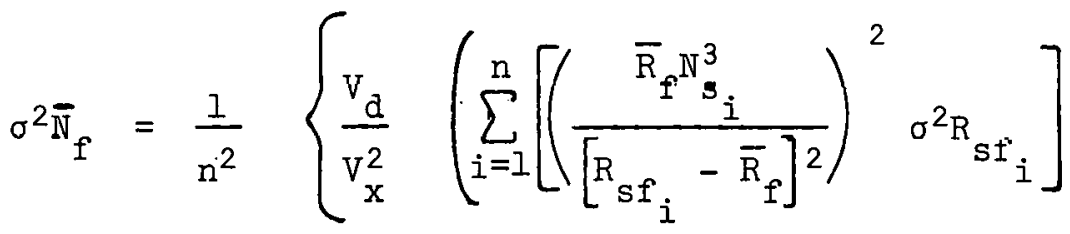

$$
\begin{aligned}
& +\sum_{i=1}^{n}\left[\left(\frac{\bar{R}_{f}}{\left[R_{s f_{i}}-\bar{R}_{f}\right]}\right)^{2} \sigma^{2} N_{s_{i}}^{3}\right]+\left[\sum_{i=1}^{n}\left(\frac{R_{s f} N_{i} s_{i}}{\left[R_{s f}-\bar{R}_{f}\right]^{2}}\right)\right]^{2} \sigma^{2} \bar{R}_{f} \\
& \left.+\frac{1}{v_{x}^{2}}\left[\sum_{i=1}^{n} \frac{\bar{R}_{f} N_{i}^{3}}{\left[R_{s f_{i}}-\bar{R}_{f}\right]}\right]^{2} \sigma^{2} v_{x}\right] \\
& \left.+\frac{1}{v_{x}^{2}}\left[\sum_{i=1}^{n} \frac{\bar{R}_{f} N_{i}^{3}}{\left[R_{s f}-\bar{R}_{f}\right]}\right]^{2} \quad \sigma^{2} v_{d}\right\}
\end{aligned}
$$

39. 


\section{THIS PAGE \\ WAS INTENTIONALLY \\ LEFT BLANK}


APPENDIX II

PROCEDURE FOR THE SEPARATION

AND MASS SPECTROMETRIC ANALYSIS

OF FISSION PRODUCT ZIRCONIUM

R. M. Abernathey, F. L. Lisman, S. F. Marsh, R. E. McAtee, G. D. Workman M. E. Kussy 
THIS PAGE

WAS INTENTIONALLY

LEFT BLANK 
PREPARATION OF Zr-90 SPIKE

A 1.6-mg sample of isotopically enriched $\mathrm{Zr}-90$, obtained from ORNL as the oxide, was fused with potassium pyrosulfate.

The melt was dissolved in sulfuric acid and diluted to approximately 1 li.ter wi.th $6 \mathrm{M} \mathrm{HCl}$. Weighed 3-ml aliquots were transferred to glass ampoules which were flame sealed.

\section{CALIBRATION OF Zr-90 SPIKE}

The calibration technique was isotope dilution mass spectrometry with natural zirconium as the primary standard. The natural zirconium standard was prepared from high purity zirconium metal. The metal was dissolved with bromine-methanol, then diluted with $6 \mathrm{M} \mathrm{HCl}$ to an approximate concentration of $3.5 \mathrm{mg} \mathrm{Zr} / \mathrm{g}$ solution. Five $\sim 25 \mathrm{mg}$ aliquots were gravimetrically analyzed by mandelate precipitation followed by ignition. to the oxide at $1000^{\circ} \mathrm{C}$ to constant weight. The relative standard deviation of the average was better than $0.2 \%$. Weight aliquots of approximately $1 \mathrm{~g}$ of the standardized solution were transferred to glass ampoules which were flame sealed. One l-g weight aliquot of the standardized solution was diluted 1000-fold on a weight basis with 6M HCI from which eight $1-g$ weight aliquots were individually combined with eight weight aliquots of the $\mathrm{Zr}-90$ spike solution. The eight mixtures then were analyzed by isotope dilution mass spectrometry. The determined concentration of the $\mathrm{Zr}-90$ "spike" was $6.7642 \times 10^{15}$ atom/g with a relative standard deviation for the average of $0.40 \%$.

\section{CHEMICAL SEPARATION}

1. To a 40-ml centrifuge tube, add the enriched $\mathrm{Zr}-90$ spike, $1 \mathrm{mg}$ of high purity thorium carrier, one drop of $30 \% \mathrm{H}_{2} \mathrm{O}_{2}, 2 \mathrm{ml}$ of $15.7 \mathrm{M} \mathrm{HNO}_{3}$, and $10 \mathrm{ml}$ of $0.35 \mathrm{M}$ $\mathrm{HIO}_{3}$.

2. Allow $5 \mathrm{~min}$ for thorium iodate to precipitate.

3. Centrifuge and discard the supernatant solution.
A borosilicate glass centrifuge tube may be used. If only isotopic distribution results are desired, omit the $\mathrm{Zr}-90$ spike. 
4. Dissolve the precipitate in a few drops of $12 \mathrm{M} \mathrm{HCl}$, add $\mathrm{I}$ drop of $30 \% \mathrm{H}_{2} \mathrm{O}_{2}$, and heat to expel the free iodine.

5. Add $2 \mathrm{ml}$ of $15.7 \mathrm{M} \mathrm{HNO}_{3}$ and heat to destroy the $\mathrm{HCl}$.

6. Add 1 drop of $30 \% \mathrm{H}_{2} \mathrm{O}_{2}$ and 10 $\mathrm{ml}$ of $0.35 \mathrm{M} \mathrm{HIO}_{3}$.

7. Allow $5 \mathrm{~min}$ for thorium iodate to precipitate.

8. Centrifuge and discard the supernatant solution.

9. Dissolve the precipitate in a few drops of $15 \mathrm{M}$ HCl and add

1 drop of $30 \% \mathrm{H}_{2} \mathrm{O}_{2}$.

10. Evaporate the sample to dryness.

11. Dissolve the residue in $1 \mathrm{ml}$ of quartz-distilled (QD) $10.6 \mathrm{M} \mathrm{HCl}$.

12. Pass the dissolved residue through a small Dowex $1 \times 8$ (100 to 200 mesh) column.

13. Thoroughly wash the column with QD 10.6M HCl. Discard the washings.

14. Elute the adsorbed zirconium with $\mathrm{QD} 4 \mathrm{M} \mathrm{HCl}$.

15. Evaporate the effluent to approximately $0.1 \mathrm{ml}$ and transfer it to the mass laboratory.
The evolution of free iodine may be tested with moistened starch paper held above the tube.

Fill a 2-ml polyethylene medicine dropper with approximately 1 in. of Dowex $1 \times 8$ resin. Do not use glassware for the column nor in any sulsequelit steps. Polypropylene ware is recommended for the subsequent steps. 
1. Prepare a triple filament assembly from high purity, 1- x 30-ml rhenium ribbon and vacuum bake it for $1 \mathrm{hr}$ at $4 \mathrm{~A}$ at a pressure of $1 \times 10^{-6}$ torr.

2. Using a new, freshly washed, transfer pipet, transfer the solution from step 15 (previous section) to the sample filaments. Evaporate the solution by passing $1.5 \mathrm{~A}$ through the filament.

3. Mount the filament holder on the ion source carriage and insert the carriage in the vacuum lock.

4. Adjust the center filament current to $3.5 \mathrm{~A}$ and the sample filament currents to $2.5 \mathrm{~A}$. Locate the major isotope beam by reference to the mass- vs-DVM (accelerating voltage) curve for the magnetic field in use. Adjust the source voltage divider controls for the maxlmum uedul. Make a iapia voltage scan in both direstions to verify the mass identification.

Allow about l-min pumping time at each lock stage.

Use the electron multiplier. Keep the J2 setting low, the J10 setting maximum and the J4-J5 setting near center. The source may need to be rotated to get $\mathrm{J} 4-\mathrm{J} 5$ centered with the maximum beam.

5. Increase the filament current to obtain a multiplier output. current of $3 \times 10^{-9} \mathrm{~A}$. Scan the spectrum magnetically in both directions, recording the sensitivity settings used to give near full-scale peak heights. Obtain 3 charts of $4 \frac{1}{2}$ double scans.

6. Graphically interpolate by drawing lines on the chart which connect the tops of the successive peaks of each isotope. Draw vertical lines on the chart at each turnaround in the scans. and take peak 
height readings at the intersection of these lines with those connecting the peak tops. Sum the readings for each isotope.

7. Correct for mass discrimination. Because the detected beam is $\mathrm{ZrO}^{+}$, corrections must be made for the $0^{17}$ and $0^{18}$ contributions at the $\mathrm{Zr}(\mathrm{A}+I)$ and $\mathrm{Zr}(\mathrm{A}+2)$ peaks.

If atom percent of an individual isotope is desired, it is given by:

atom $\% \mathrm{Zr}^{\mathrm{A}}=$ $100 \cdot \frac{\sum \text { corr peak heights }}{\sum\left(\sum \text { corr peak heights }\right)}$

\section{CALCULATIONS̈}

The isotopic distribution of the various zirconium fission product isotopes is obtained from unspiked samples.

To correct for natural zirconium contamination,

let:

$A_{0}=$ relative atom: abundance of $\mathrm{Zr}-90$ to total zirconium in sample.

$\mathrm{B}_{0}=$ relative atom abundance of fission product $\mathrm{Zr}-90$ in total fission proninet zirsonium.. (Thic io obtaincd by a computer calculativi and is .less than $1.5 \%$.)

$\mathrm{C}_{0}=$ natural abundance of $\mathrm{Zr}-90$.

$\mathrm{Z}$ = relative atom abundance of total fission product zircunium to total zirconium in the sample.

$\mathrm{x}_{\mathrm{n}}=$ relative atom abundance of naturol rirconium to total zirconium in the sample.

Then:

$$
A_{0}-C_{0} X_{n}=B_{0} Z
$$

assuming that the zirconium in the sample is composed only of fission product zirconium and natural zirconium.

Then:

$$
x_{n}+z=1
$$


or

$$
\mathrm{z}=1-\mathrm{X}_{\mathrm{n}}
$$

The relative atom abundance of natural zirconium to total zirconium in the unspiked sample is:

$$
x_{n}=\frac{\left(A_{0}-B_{0}\right)}{\left(C_{0}-B_{0}\right)}
$$

Let $B_{i}=$ relative atom abundance of a particular fission product zirconium isotope to the total zirconium in the sample.

and:

$$
B_{i}=A_{i}-C_{i} X_{n}
$$

The atom ratio of two. fission product zirconium isotopes $R_{f_{(i / j)}}$ is :

$$
R_{(i / j)}=\frac{B_{i}}{B_{j}}
$$

nr

$$
R_{(i / j)}=\frac{A_{i}-C_{i} X_{n}}{A_{j}-C_{j} X_{n}}
$$

where:

$$
\begin{aligned}
A_{i}, A_{j}= & \text { relative atom abundance of a particular zirconium isotope, } \\
& \text { to the total zirconium in the sample. } \\
C_{i}, C_{j}= & \text { natural atom abundance of the } i^{\text {th }} \text { or } j^{\text {th }} \text { zirconium isotope. }
\end{aligned}
$$

To calculate the number of atoms of each fission product zirconium isotope the spiked samples are used.

To calculate the number of fission product zirconium atoms in the sample. Let:

$$
R_{s f(i / j)}=\begin{aligned}
& \text { atom ratio of } i^{\text {th }} \text { zirconium isotope to the } j^{\text {th }} \text { zirconium } \\
& \text { isn the spiked fission product sample. }
\end{aligned}
$$




$$
\begin{aligned}
& \begin{aligned}
N_{S}^{i}= & \text { number of "spike" atoms of the } i^{\text {th }} \text { fission product } \\
& \text { zirconium isotope in the sample. }
\end{aligned} \\
& \begin{aligned}
N_{f}^{i}= & \text { number of atoms of the } i^{\text {th }} \text { fission product zirconium } \\
& \text { isotope in the sample. }
\end{aligned} \\
& \mathrm{N}_{\mathrm{n}}^{\mathrm{i}}=\begin{array}{l}
\text { number of atoms of the } i^{\text {th }} \text { zirconium isotope in the sample } \\
\text { due to natural zirconium contamination. }
\end{array} \\
& \bar{R}_{f(i / j)}=\text { fission product atom ratio of the } i^{\text {th }} \text { zirconium isotope } \\
& \text { obtained from several unspiked samples.) } \\
& \begin{aligned}
R_{n}(i / j) & \text { ratio of the natural atom abundances of the } i^{\text {th }} \text { to } j^{\text {th }} \\
& \text { zirconium isotopes. }
\end{aligned}
\end{aligned}
$$

To calculate the number of fission product $\mathrm{Zr}-9 \mathrm{l}$ atoms in the sample:

$$
R_{S_{f(91 / 93)}}=\frac{N_{s}^{91}+N_{f}^{91}+N_{n}^{91}}{N_{f}^{93}}
$$

or

$$
R_{s f_{(91 / 93)}}=\frac{R_{s(91 / 93)} N_{s}^{90}+N_{f}^{91}+R_{n(91 / 90)} N_{n}^{90}}{R_{f}}
$$

now

$$
R_{S f(90 / 93)}=\frac{N_{s}^{90}+N_{f}^{90}+N_{n}^{90}}{N_{f}^{93}}
$$

or

$$
N_{n}^{90}=N_{f}^{93} R_{s f}(90 / 93)-N_{s}^{90}-N_{f}^{90}
$$

or

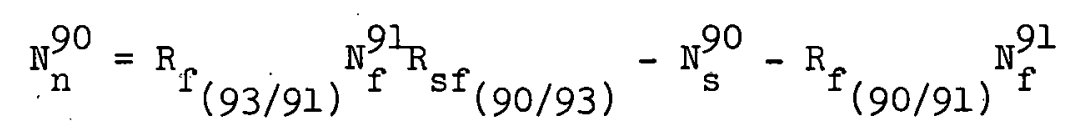


substituting for $\mathrm{N}_{\mathrm{n}}^{90}$ in equation (1) yields:

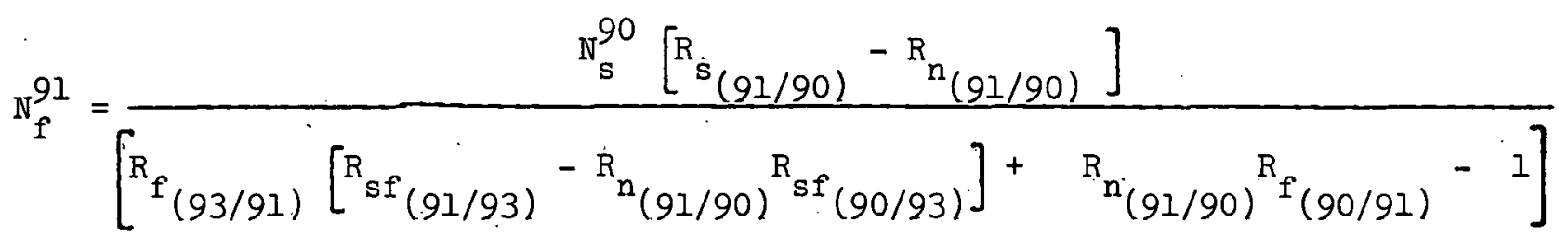

To calculate the number of fission product atoms of $\mathrm{Zr}-92, \mathrm{Zr}-93, \mathrm{Zr}-94$, and $\mathrm{Zr}-96$ in the sample:

$$
\begin{aligned}
& \mathrm{N}_{f}^{92}=\bar{R}_{f_{(92 / 91)}} \mathrm{N}_{f}^{91} \\
& \mathrm{~N}_{f}^{93}=\bar{R}_{f_{(93 / 91)}} \mathrm{N}_{f}^{91} \\
& \mathrm{~N}_{f}^{94}=\bar{R}_{f(94 / 91)} \mathrm{N}_{f}^{91} \\
& N_{f}^{96}=\bar{R}_{f(96 / 91)} N_{f}^{91}
\end{aligned}
$$

where:

$N_{f}^{9 l}=$ number of fission product $\mathrm{Zr}-91$ atoms in the sample. 